\title{
Proximate Analysis and Elemental Composition of Vigna membranacea Seeds
}

\author{
Abdullahi Nasir ${ }^{*} \quad$ Muhammad Ibrahim Usman ${ }^{2}$ \\ 1.Department of Biochemistry, Faculty of Natural and Applied Sciences, Umaru Musa Yar'adua University, \\ P.M.B. 2218, Katsina, Nigeria \\ 2.Department of Medical Biochemistry, College of Medical Sciences, Yobe State University Damaturu, Yobe. \\ Nigeria
}

\begin{abstract}
This study was conducted to investigate the proximate composition and toxic metals composition of Vigna membranacea cultivated in Kano state, Nigeria. The results of proximate composition showed the presence of ash, protein, crude fibre, moisture, Lipid and carbohydrate. From the result obtained, carbohydrate was found to be the dominant nutrient in the seed, followed by ash content, then protein content, then moisture content, crude fibre and finally lipid. Elemental analysis revealed the presence of the following toxic elements: lead $(\mathrm{Pb})$, Cobalt (Co), Nickel (Ni) and Chromium (Cr) with Chromium been the highest while cobalt was found to be lowest. For the non-toxic elements, Zinc ( $\mathrm{Zn}$ ) was recorded to be the dominant element, followed by Calcium $(\mathrm{Ca})$, then Manganese $(\mathrm{Mn})$, then Potassium $(\mathrm{K})$, then Magnesium $(\mathrm{Mg})$, followed by Iron $(\mathrm{Fe})$ with Copper $(\mathrm{Cu})$ been the lowest. The results obtained from the present studies could be a source of valuable information and a guideline for food scientists, researchers and even the legume consumers not only in Nigeria but all over the world where this seed is found.
\end{abstract}

Keywords: Proximate analysis, Elemental analysis, Vigna membranacea and seeds.

DOI: $10.7176 / \mathrm{FSQM} / 91-07$

Publication date:October $31^{\text {st }} 2019$

\subsection{INTRODUCTION}

Vegetables make up a major portion of the diet of humans in many parts of the world and play a significant role in human nutrition, especially as sources of phyto-nutraceuticals: vitamins $\left(C, A, B_{1}, B_{6}, B_{9}, E\right)$, minerals, dietary fiber and phytochemicals. Some phytochemicals of vegetables are strong antioxidants and are thought to reduce the risk of chronic disease by protecting against free-radical damage, modifying metabolic activation and detoxification of carcinogens, or even influencing processes that alter the course of tumor cells (Khairiah et al., 2002). Vegetables in the daily diet have been strongly associated with overall good health, improvement of gastrointestinal health and vision, reduced risk for some forms of cancer, heart disease, stroke, diabetes, anaemia, gastric ulcer, rheumatoid arthritis, and other chronic diseases (Obizoba, 1998). A high vegetable diet has been associated with lower risk of cardiovascular disease in humans while Low vegetable intake has been estimated to cause about $31 \%$ of ischemic heart disease and $11 \%$ of stroke worldwide (Halliwell and Gutteridge, 1992). According to World Health Report unbalanced diets with low vegetable intake and low consumption of complex carbohydrates and dietary fiber are estimated to cause some 2.7 million deaths each year, and were among the top 10 risk factors contributing to mortality. The exact mechanisms by which vegetable consumption reduces human diseases have not yet been fully understood, however the general consensus among physicians and nutritionists is that phytonutraceuticals in vegetables are responsible for mitigating some of these diseases.

Toxic metals are example of heavy metals that variously defined to have higher atomic number (Norman, 1981), associated with little or no biochemical functions. However; they have many industrial and agricultural applications (Alloway, 1995) and are generally metallic of relatively high density with potential toxicity at low concentration (Holding, 2004). According to WHO (2014), toxic metals occur in trace amount and are at least five times denser than water, They are stable and persistent in environmental samples, hence bioaccumulates to pass up via food chain to humans. According to Alhassan et al (2012) sources of heavy metals are varied and include natural sources and all human activities, which have the possibility of polluting the environment, in other perspective, environmental toxic metals are mainly direct deposition from mining activities, industrial processes as well as waste water from domestic processes, in addition to agricultural practices (Madyiwa, 2006). Heavy metals contamination to agricultural soils could be through a variety of sources among which is land application of bio solids, fertilizers, livestock manure, agrochemicals (Pesticides), irrigation activities and atmospheric droplet. Worthy of consideration is accumulation of these metals in agricultural soils and possible negative impacts on soil fertility and large potential accumulation in crops for possible incorporation to human food chains (Gray et al., 2003). Unlike the inorganic, the organic (alkylated) forms are readily taken up by body tissues and can be retained for a considerable length of time (Garrett et al., 1992) this is due to their lipid solubility. The tissue penetrating power of organometals crown them more toxic to humans than the inorganic form (Carpenter, 2001). 
Vigna membranacea is a leguminous beans belonging to the Vigna specie, although it is readily available in northern region of Nigeria, it is underutilized because of speculations that it has some anti-nutritional or elemental components which make it toxic. This study was therefore aimed at determining the proximate composition and the toxic minerals of Vigna membranacea.

\subsection{MATERIALS AND METHODS}

\subsection{Collection and Preparation of Vigna membranacea seed}

Fresh and apparently uninfected seeds of Vigna membranacea were collected from their natural habitat in Bari, Rogo Local Government area of Kano State on September, 2015. The samples were shade dried and identified by a plant taxonomist of the Department of Botany, Bayero University Kano, Nigeria. 200g of the seeds were dehulled and grounded manually using an aluminium mortar to fine flour, packaged and labeled appropriately.

\subsection{Proximate Analysis}

Ten gram $(10 \mathrm{~g})$ of the flour was soaked in $100 \mathrm{ml}$ of pre-boiled distilled water. The solution was shook vigorously and allowed to stand for 24 hours. It was then filtered using Whatman's No. 1 filter paper and concentrated by freeze-drying to solvent free extract. The proximate analysis of the seed extract for moisture, ash, fibre carbohydrate, crude protein and fat contents were determined as described by AOAC standard assay method (AOAC, 2005).

\subsection{Elemental Determination}

Five gram $(5.0 \mathrm{~g})$ of the prepared samples were air dried, ground in an agate mortar and was placed in quartz crucibles for dry ashing and mineralized thermally in a muffle furnance at $450^{\circ} \mathrm{C}$ for $12 \mathrm{hrs}$. The mineralized samples was then acid digested by dissolving in $20 \mathrm{ml}$ of $1: 1(\mathrm{v} / \mathrm{v})$ concentrated $\mathrm{HNO}_{3}$ and $\mathrm{HCl}$ acids in $100 \mathrm{ml}$ volumetric flask. The flask was then heated in an electro thermal heater with gentle swirling till digestion completed by evolution of white fumes. The cooled digests was filtered through Whatman No 1 filter paper into $50 \mathrm{ml}$ volumetric flask and was diluted to $50 \mathrm{ml}$ mark with de-ionized water. The heavy metals content of the samples were determined using the atomic absorption spectrophotometer (AAS) and calculated using the relation $y=m x+c$ from calibration of each metal standard (AOAC, 2005).

\subsection{RESULT AND DISCUSSION}

\subsection{Results}

Figure 1 presents the proximate composition of Vigna membranacea cowpea. The results revealed that processing had no significant effect $(\mathrm{P}>0.05)$ on the following proximate composition in Vigna membranacea cowpea analysed: Crude protein, carbohydrate, ash, crudefibre and moisture contents. Carbohydrate was found to be the highest proportion with a percentage of $42.50 \pm 0.02$, followed by protein with $21.22 \pm 0.01$. The least is fat with percentage composition of $1.16 \pm 0.01$.

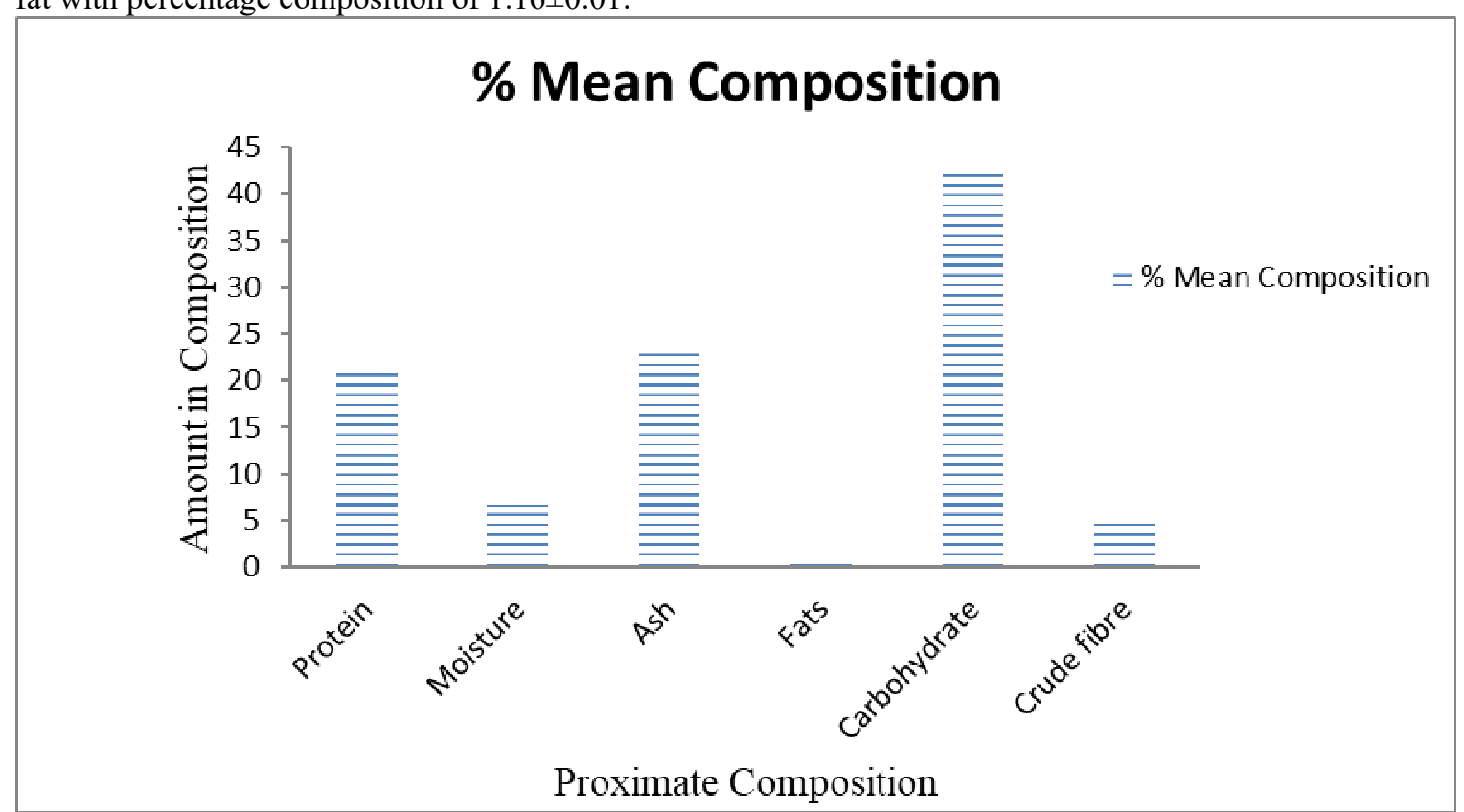

Table 1: Proximate Analysis of Vigna membranacea seed

Table 1 shows the mineral components of the Vigna membranacea per $100 \mathrm{~g}$ of the sample. Zinc (Zn) was 
observed to be dominant in the seed with an amount $172.23 \mu \mathrm{g} / 100 \mathrm{~g}$, followed by other mineral element that are significantly in low quantity.

Table 1: The Table below Shows the Mineral Contents of Vigna membranacea in $\mu \mathrm{g} / 100 \mathrm{~g}$

\begin{tabular}{|l|l|l|l|l|l|l|l|l|}
\hline $\mathbf{P b}$ & $\mathbf{Z n}$ & $\mathbf{M n}$ & $\mathbf{F e}$ & $\mathbf{C r}$ & $\mathbf{C u}$ & $\mathbf{N i}$ & $\mathbf{K}$ & $\mathbf{C a}$ \\
\hline $1.45 \pm 0.2$ & $172.23 \pm 3$. & $5.83 \pm 1.1$ & $3.09 \pm 1.3$ & $3.09 \pm 1.1$ & $1.52 \pm 0.2$ & $1.92 \pm 0.1$ & $4.44 \pm 1.0$ & $6.94 \pm 2.1$ \\
1 & 2 & 0 & 5 & 5 & 1 & 0 & 5 & 0 \\
\hline
\end{tabular}

\subsection{Discussion}

Diet must provide macro and micro elements. The moisture content is the loss on drying at oven temperature of $100^{\circ} \mathrm{C}$. Besides water, the loss will include other volatile matter at $100^{\circ} \mathrm{C}$. The samples had a moisture content of $7.89 \%$. This moisture content is safe for storage the results for the moisture content of the seed was comparable with 4.85, 5.21 and 6.10 reported for Colocynthis citrullus from Akure Cucumeropsis edulis prumus and amygdalus seed flour respectively (Akpambang et al., 2008). The result of the ash content yields 25.67\% indicating that the seeds will be a good source of minerals. Since the ash content of a sample is a reflection of the minerals it contains therefore, pumpkin seeds are expected to be rich in minerals needed for good body development (Hamed et al., 2008). The crude fat content showed that the pumpkin seeds contain a good amount of oil that can be exploited i.e (be refined to edible vegetable oil for domestic use). This value fell in the range reported for different species of legumes (Stevenson et al., 2007). The recommended daily allowance (RDA) of fiber are 19 to 25,21 to 38,28 and 29\%, for children, adults, pregnant and lactating mothers respectively. Thus the seeds can be considered as a valuable source of dietary fiber in human nutrition. Fibre rich foods are normally prescribed to diabetics for reduction of glycemic response to the food and consequently the need for insulin (Guillon and Champ, 2000). Legumes and cereals have relatively low mineral contents Legumes and nuts are rich sources of copper. The result obtained for copper is in accordance with the study of Opeolu et al (2010) investigated the mineral content of six varieties of beans that were taken from seven different regions in northwestern Argentina.

\subsection{CONCLUSION}

The research revealed Vigna membranacea to be nutritionally rich. However, excess consumption of this seed as food by both humans and animals can lead to the fast increase of mineral element in the body which can result to metabolic diseases. Therefore the use of the seed as food should be minimized.

\section{Reference}

AOAC. (2005). Official Methods of Analysis International, $18^{\text {th }}$ edition, Association of Official Analytical Chemists, Washington DC.USA pp. 6-8.

Akpambang V.O.E., Amoo I.A. and Zuagie I. (2008). Comparative compositional analysis on two varieties of melon (Colocynthis citrullus). African Journal of Biotechnology, 4: 1329-1334.

Alhassan, A.J. Sule, M.S. Atiku, M.K., Wudil, A.M., Dangambo, M.A., Mashi, J.A. and Ibrahim, N.A. (2012). Study of Correlation between Heavy Metal Concentration, Street Dust and Level of Traffic in Major Roads of Kano Metropolis, Nigeria.

Alloway B.J (1995). Heavy metals in soils $2^{\text {nd }}$ edition, Blackie academic and professional, Glasgow, Pp. 500.

B. O. Opeolu, O. O. Adenuga, P. A. Ndakidemi and O. O. Olujimi (2010). Assessment of phyto-toxicity potential of lead on tomato (Lycopersiconesculentum L) planted on contaminated soils. International Journal of Physical Sciences Vol. 5 (2): 68-73.

Carpenter D.O. (2001). Effects of metals on the nervous system of Humans and metals. International Journal of Occapational medicine and Environmental Health. U.S. 14(3): 209-218.

Garrett R.J.B, Archdeacon J.W. (1992). Placental transmission of mercury to foetal rat. Toxicological Application pharmacological. 22: 649-654.

Gray C.W, Mclaren R.C, Roberts A.H.C. (2003). Atmospheric accessions of heavy metals to some New Zealand pastoral soils. The science of the total Environment. 305: 105-115.

Guillon F. and Champ M. (2000) Effects of Drying on the Physicochemical and Functional Properties of Green Banana (Musa sapientum) Flour and Development of Baked Product Journal of Food Research International, 32, 233-245.

Halliwell B, Gutteridge JMC (1992). Free radicals, antioxidants and human diseases: where are we now? J. Lab. Clinic. Med. 119:598- 620.

Hamed S.Y., El Hassan N.M., Hassan A.B., Eltayeb M.M., and Babiker E.E. (2008) Nutritional Evaluation and Physiochemical Properties of Processed Pumpkin ( Telfairia occidentalis Hook) Seed Flour. Pakistan Journal of Nutrition, 7(2): 330-334.

Holding B.V. (2004). Heavy metals. (http;www.lenteh.com).

Khairiah J, Yu H, Y, Khairal NI, Ang WW, Aminah A, Maimon A, Zalifah M K, Geri AK (2002). 
Bioavailability of chromium in vegetables of selected Agricultural areas of Malaysia. Pak. J. Biol. Sci. 5(4): 471- 473.

Madyiwa S. (2006). Modeling lead and cadmium uptake by star Grass under irrigation with treated waste water. Published philosophiae. Doctor Thesis, University of Pretoria, South Africa. Pp4.

Norman M.T. (1981). Environmental and Health. Michigan University. Pp. 367-406.

Obizoba IC (1998). Fermented Food. In: Nutritional Quality of Plant Foods. Osagie AU, Eka, OU (eds). PostHarvest Res Unit, University of Benin City. Pp $160-198$.

Stevenson D.G., Eller F.J., Wang L., Jane J.L., Wang T. and Inglett G.E. (2007).Oil and tocopherol content and composition of pumpkin seed oil in 12 cultivars. Journal of Agriculture and Food Chemistry, 55: 4005-4013.

World Health Organization (2014) WHO Food Additive Series 52. Safety evaluation of certain food additives and contaminants. International programme on chemical safety. http://whqlibdoc.who.int/publications. 